\title{
Responses of soil nitrous oxide production and abundances and composition of associated microbial communities to nitrogen and water amendment
}

\author{
Qing Wang ${ }^{1,2}$ • Yu-Rong Liu ${ }^{1,2}$ • Cui-Jing Zhang ${ }^{1,2}$ • Li-Mei Zhang ${ }^{1,2} \cdot$ Li-Li Han $^{1,2}$ • \\ Ju-Pei Shen ${ }^{1,2} \cdot$ Ji-Zheng He $\mathrm{He}^{1,2,3}$
}

Received: 4 January 2017 /Revised: 31 March 2017 / Accepted: 4 April 2017 /Published online: 17 April 2017

(C) Springer-Verlag Berlin Heidelberg 2017

\begin{abstract}
Soil moisture and nitrogen $(\mathrm{N})$ are two important factors influencing $\mathrm{N}_{2} \mathrm{O}$ emissions and the growth of microorganisms. Here, we carried out a microcosm experiment to evaluate effects of soil moisture level and $\mathrm{N}$ fertilizer type on $\mathrm{N}_{2} \mathrm{O}$ emissions and abundances and composition of associated microbial communities in the two typical arable soils. The abundances and community composition of functional microbes involved in nitrification and denitrification were determined via quantitative PCR (qPCR) and terminal restriction length fragment polymorphism (T-RFLP), respectively. Results showed that $\mathrm{N}_{2} \mathrm{O}$ production was higher at $90 \%$ water-filled pore (WFPS) than at 50\% WFPS. The $\mathrm{N}_{2} \mathrm{O}$ emissions in the two soils amended with ammonium were higher than those amended with nitrate, especially at relatively high moisture level. In both soils, increased soil moisture stimulated the growth of ammonia-oxidizing bacteria (AOB) and nitrite reducer (nirK). Ammonium fertilizer treatment increased the population size of $\mathrm{AOB}$ and nirK genes in the alluvial soil, while reduced the abundances of ammonia-oxidizing archaea (AOA) and denitrifiers (nirK and nosZ) in the red soil. Nitrate addition had a negative effect on AOA abundance in the red
\end{abstract}

Electronic supplementary material The online version of this article (doi:10.1007/s00374-017-1203-3) contains supplementary material, which is available to authorized users.

Yu-Rong Liu

yrliu@rcees.ac.cn

1 State Key Laboratory of Urban and Regional Ecology, Research Center for Eco-Environmental Sciences, Chinese Academy of Sciences, Beijing 100085, China

2 University of Chinese Academy of Sciences, Beijing 100049, China

3 Faculty of Veterinary and Agricultural Sciences, The University of Melbourne, Parkville, Victoria 3010, Australia soil. Total $\mathrm{N}_{2} \mathrm{O}$ emissions were positively correlated to AOB abundance, but not to other functional genes in the two soils. Changed soil moisture significantly affected AOA rather than AOB community composition in both soils. The way and extent of $\mathrm{N}$ fertilizers impacted on nitrifier and denitrifier community composition varied with $\mathrm{N}$ form and soil type. These results indicate that $\mathrm{N}_{2} \mathrm{O}$ emissions and the succession of nitrifying and denitrifying communities are selectively affected by soil moisture and $\mathrm{N}$ fertilizer form in the two contrasting types of soil.

Keywords Nitrification - Denitrification · Nitrous oxide · Arable soils $\cdot$ Soil moisture $\cdot$ Nitrogen amendment $\cdot$ Nitrifier Denitrifier

\section{Introduction}

Nitrous oxide $\left(\mathrm{N}_{2} \mathrm{O}\right)$ is one of the most important greenhouse gases that contribute to global warming and ozone destruction in the stratosphere (Ravishankara et al. 2009). Globally, soils are major sources of $\mathrm{N}_{2} \mathrm{O}$ emissions, and $60 \%$ (3.5 Tg N year ${ }^{-1}$ ) of $\mathrm{N}_{2} \mathrm{O}$ emissions are derived from arable soils (Goldberg and Gebauer 2009; IPCC 2013). There is little doubt that increasing atmospheric concentration of $\mathrm{N}_{2} \mathrm{O}$ is primarily caused by the excessive use of nitrogen $(\mathrm{N})$ fertilizer (Davidson 2009; Shcherbak et al. 2014; Zhu et al. 2015). However, $\mathrm{N}_{2} \mathrm{O}$ production from $\mathrm{N}$ fertilizer depends mainly on soil properties but also by soil moisture and the type of $\mathrm{N}$ fertilizer (Zhu et al. 2013b; Cheng et al. 2014; Wang et al. 2016a; Zhang et al. 2016).

$\mathrm{N}_{2} \mathrm{O}$ emissions in soils mainly occur through microbialmediated nitrification and denitrification (Wrage et al. 2001; Liu et al. 2016). Nitrification-associated pathways are performed by ammonia oxidizers through oxidizing ammonium 
$\left(\mathrm{NH}_{4}{ }^{+}\right)$to nitrite $\left(\mathrm{NO}_{2}{ }^{-}\right)$and emit $\mathrm{N}_{2} \mathrm{O}$ under aerobic conditions, but this can happen via the reduction of $\mathrm{NO}_{2}^{-}$by ammonia-oxidizing bacteria (AOB) (Shaw et al. 2006; Kim et al. 2010; Hu et al. 2015a). Under anaerobic conditions, $\mathrm{N}_{2} \mathrm{O}$ is the intermediate product of denitrification where denitrifiers reduce nitrate $\left(\mathrm{NO}_{3}{ }^{-}\right)$to dinitrogen $\left(\mathrm{N}_{2}\right)$ through $\mathrm{NO}_{2}{ }^{-}$, nitric oxide (NO), and $\mathrm{N}_{2} \mathrm{O}$ (Baggs 2011). Soil moisture, usually measured by the water-filled pore space (WFPS), regulates oxygen $\left(\mathrm{O}_{2}\right)$ concentration and controls the aerobic and anaerobic conditions in the soil, which can affect the relative contribution of nitrification and denitrification to $\mathrm{N}_{2} \mathrm{O}$ emissions (Stevens et al. 1997; Bateman and Baggs 2005; Kool et al. 2011; Cheng et al. 2014; Liu et al. 2017). Nitrification is believed to be the primary pathway of $\mathrm{N}_{2} \mathrm{O}$ production in well-aerated soils with $30 \%<$ WFPS $<60 \%$, while denitrification is the major source in wet soils with WFPS of $>60 \%$ (Bateman and Baggs 2005; Kool et al. 2011). Besides, soil moisture is a key factor influencing diffusion and transport of nutrients, such as dissolved organic $\mathrm{C}$ and $\mathrm{N}$ availability, which in turn affects microbial community composition and activities in soils (Gleeson et al. 2010; Hu et al. 2015b; Banerjee et al. 2016). Although efforts have been devoted to revealing the impact of soil moisture on $\mathrm{N}_{2} \mathrm{O}$ emission pathways, it is still unclear how soil moisture affects the growth of nitrifiers and denitrifiers and their roles in $\mathrm{N}_{2} \mathrm{O}$ emissions from the contrasting arable soils.

$\mathrm{N}$ fertilizer application (ammonium and nitrate fertilizers) has been recognized as another important factor influencing $\mathrm{N}_{2} \mathrm{O}$ emissions from arable soils (Zhu et al. 2013a; Rosa et al. 2016; Zhang et al. 2016; Krauss et al. 2017) because it provides substrates for driving soil nitrification and denitrification processes. Application of ammonium fertilizer can produce $\mathrm{N}_{2} \mathrm{O}$ by nitrification, be converted to $\mathrm{NO}_{3}{ }^{-}$, while $\mathrm{NO}_{3}{ }^{-}$in soils can produce $\mathrm{N}_{2} \mathrm{O}$ by denitrification (Del Prado et al. 2006). However, the effects of different forms of $\mathrm{N}$ addition on nitrifier and denitrifier communities and subsequent $\mathrm{N}_{2} \mathrm{O}$ emissions in response to altered soil moisture conditions have not been well explored.

Beyond the significant impact of soil moisture and $\mathrm{N}$ fertilizer type, soil type determines soil physicochemical characteristics (e.g., soil texture and $\mathrm{pH}$ ), which is important in shaping microbial community composition and regulating $\mathrm{N}_{2} \mathrm{O}$ production (Wang et al. 2015). Soil texture regulates soil $\mathrm{N}_{2} \mathrm{O}$ emissions through influencing $\mathrm{O}_{2}$ availability (Corre et al. 1999), because soil texture can affect the size and distribution of soil pores and therefore influence soil aeration and water content (Singurindy et al. 2006; Chen et al. 2013a). Soil $\mathrm{pH}$ has been identified as another key regulator of soil $\mathrm{N}_{2} \mathrm{O}$ emissions (Butterbach-Bahl et al. 2013), and product ratios of $\mathrm{N}_{2} \mathrm{O} /\left(\mathrm{N}_{2}+\mathrm{N}_{2} \mathrm{O}\right)$ have a significantly negative relationship with soil $\mathrm{pH}$ within the normal range from $\mathrm{pH} 5$ to 8 in agricultural soils (Chapuis-lardy et al. 2007). Further, the activity of AMO, NIRK, or NOS is impacted by $\mathrm{pH}$ and $\mathrm{O}_{2}$ availability (Giles et al. 2012; Banerjee et al. 2016). Thus, the effects of water and $\mathrm{N}$ fertilizer amendment on $\mathrm{N}_{2} \mathrm{O}$ emissions and community composition of functional guilds might depend on soil type.

The mechanisms of global change (e.g., water and $\mathrm{N}$ amendment) impact on $\mathrm{N}_{2} \mathrm{O}$ emissions remain not well completely understood. Therefore, we explored the role of associated functional guilds in $\mathrm{N}_{2} \mathrm{O}$ emissions from the two typical arable soils. Therefore, two typical arable soils with different physicochemical properties were collected from northeast and southern China, respectively. Soils were amended with different types of $\mathrm{N}$ fertilizer under two different soil moisture levels, and the abundances and community composition of nitrifiers and denitrifiers were measured to investigate their responses to short-term changes in soil $\mathrm{N}$ amendment at different soil moisture levels. We hypothesized that (1) $\mathrm{N}$ fertilizer type and soil water content determined $\mathrm{N}_{2} \mathrm{O}$ emissions and predominant $\mathrm{N}$ cycling processes in the arable soils and (2) the responses of $\mathrm{N}_{2} \mathrm{O}$ emissions and the abundances and composition of associated microbial community to water and $\mathrm{N}$ amendment depended on distinct soil characteristics.

\section{Materials and methods}

\section{Soil sampling and basic properties}

Soil samples were collected from two upland fields in the summer of 2014. The first site is located in Luancheng City, Hebei Province, China ( $\left.40^{\circ} 7^{\prime} 34^{\prime \prime} \mathrm{N}, 119^{\circ} 11^{\prime} 27^{\prime \prime} \mathrm{E}\right)$, and the second one is in Qiyang County, Hunan Province, China $\left(26^{\circ}\right.$ $\left.24^{\prime} 26^{\prime \prime} \mathrm{N}, 112^{\circ} 00^{\prime} 45^{\prime \prime} \mathrm{E}\right)$. The soil in Luancheng is classified as Ustochrept (alluvial soil) according to the USDA Soil Taxonomy (USDA 1994), and the soil in Qiyang belongs to Paleudults (red soil). Soil samples were taken from the upper $15 \mathrm{~cm}$ depth, and sieved $(<2 \mathrm{~mm})$ and stored. Soil $\mathrm{pH}$ was determined in a 1:2.5 dilution with deionized water using a $\mathrm{pH}$ meter (Mettler-Toledo Instruments Co., Shanghai, China). Total $\mathrm{N}$ was determined using an Element Analyzer (Elementar, Germany). Soil organic C (SOC) was determined by wet digestion using $\mathrm{H}_{2} \mathrm{SO}_{4}$ and $\mathrm{K}_{2} \mathrm{Cr}_{2} \mathrm{O}_{7}$. Exchangeable $\mathrm{NH}_{4}{ }^{+}-\mathrm{N}$ and $\mathrm{NO}_{3}{ }^{-}-\mathrm{N}$ concentration was determined using a continuous flow analyzer (SAN++, Skalar, Breda, Holland) after extraction with $0.01 \mathrm{M} \mathrm{CaCl}_{2}$. Particle size analysis was measured using the sieve and hydrometer procedures. The main soil properties were for alluvial soil: $\mathrm{pH}, 7.8$; SOC, $9.5 \mathrm{~g} \mathrm{~kg}^{-1}$; TN, $0.89 \mathrm{~g} \mathrm{~kg}^{-1}$; exchangeable $\mathrm{NH}_{4}{ }^{+}-\mathrm{N}$, $2.4 \mathrm{mg} \mathrm{kg}^{-1} ; \mathrm{NO}_{3}{ }^{-}-\mathrm{N}, 117.8 \mathrm{mg} \mathrm{kg}{ }^{-1}$; and particle size, $58.0 \%$ sand, $28.1 \%$ silt, and $13.9 \%$ clay and for the red soil: $\mathrm{pH}, 6.2$; SOC, $22.4 \mathrm{~g} \mathrm{~kg}^{-1}$; TN, $1.51 \mathrm{~g} \mathrm{~kg}^{-1}$; exchangeable $\mathrm{NH}_{4}{ }^{+}-\mathrm{N}, 3.0 \mathrm{mg} \mathrm{kg}^{-1} ; \mathrm{NO}_{3}{ }^{-}-\mathrm{N}, 27.8 \mathrm{mg} \mathrm{kg}^{-1}$; and particle size, $4.3 \%$ sand, $53.2 \%$ silt, and $42.5 \%$ clay. 


\section{Soil microcosm incubation}

Soil microcosm experiment was conducted in 250-ml glass bottles containing $30 \mathrm{~g}$ of fresh soil. Soils for the experiment were pre-conditioned at $25^{\circ} \mathrm{C}$ in the dark for 1 week. Two different types of $\mathrm{N}$ fertilizer were applied, $\left(\mathrm{NH}_{4}\right)_{2} \mathrm{SO}_{4}\left(\mathrm{NH}_{4}{ }^{+}\right)$ and $\mathrm{KNO}_{3}\left(\mathrm{NO}_{3}{ }^{-}\right)$, and then, no fertilizer addition was set up as a control. $\mathrm{N}$ fertilizer treatments received a dose of $200 \mathrm{mg} \mathrm{N} \mathrm{kg}^{-1}$ dry soil. In order to assure uniform distribution, $\mathrm{N}$ fertilizer was added as $\mathrm{N}$ solution. Soil moisture was adjusted to either 50 or $90 \%$ WFPS with sterile deionized water. The control received deionized water to reproduce the moisture contents of the treatment samples. Each bottle was covered with Parafilm which was poked with three or four small holes to facilitate gas exchange. Three replicates were set up for each treatment. All samples were incubated for 20 days in the dark at $25^{\circ} \mathrm{C}$.

\section{$\mathrm{N}_{2} \mathrm{O}$ emission measurement and soil sampling}

Gas samples were collected at different time intervals (1, 2, 4, 7,10 , and 20 days) of 20-day incubation. Before gas collection, bottles were closed with a rubber stopper for $12 \mathrm{~h}$. Gas samples were taken from the headspace by a $20-\mathrm{ml}$ syringe. $\mathrm{N}_{2} \mathrm{O}$ concentration was determined using a Shimadzu GC14B gas chromatograph (Shimadzu GC 14B, Tokyo, Japan). The total $\mathrm{N}_{2} \mathrm{O}$ emissions were evaluated using the following equation according to Ma et al. (2009):

$\mathrm{TN}_{2} \mathrm{O}=\sum_{i=1}^{n}(R i \times D i)$

where $R i$ is the $\mathrm{N}_{2} \mathrm{O}$ emission rate in the $i$ th sampling interval, $D i$ is the number of days, and $n$ is the number of sampling intervals.

Soil moisture was checked every 3-4 days and water was supplemented if necessary. Soil samples were collected for the measurement of soil $\mathrm{pH}$ and inorganic $\mathrm{N}$ (exchangeable $\mathrm{NH}_{4}{ }^{+}-\mathrm{N}$ and $\mathrm{NO}_{3}{ }^{-}-\mathrm{N}$ ) concentration at the end of incubation. The remaining soil samples were stored at $-20{ }^{\circ} \mathrm{C}$ for molecular analysis.

\section{DNA extraction and real-time PCR (qPCR) analysis}

Total genomic DNA was extracted from $0.5 \mathrm{~g}$ fresh soil using MoBio Powersoil ${ }^{\mathrm{TM}}$ DNA Isolation Kit (Mobio Laboratories, USA). DNA extraction yields were in the range of 20.5$40.0 \mathrm{ng} / \mu \mathrm{l}$ and an A260/280 ratio of 1.75-1.90.

The abundance of ammonia oxidizers (AOA and AOB $a m o A$ ) and denitrifiers (nirK and nos $Z$ ) was estimated on iQ5 Real-Time PCR Detection System (Bio-Rad, USA). The PCR primers and thermal cycling conditions of all functional genes were listed in Table S1. The $20 \mu \mathrm{l}$ PCR mixture included $10 \mu \mathrm{l}$ of $2 \times \mathrm{SYBR}$ Premix Ex Taq ${ }^{\mathrm{TM}}, 0.5 \mu \mathrm{M}$ of each primer, and 1-10 ng of template DNA. Melting curve analysis (65-95 ${ }^{\circ} \mathrm{C}$ ) was conducted to assess the qPCR product specificity at the end of each amplification process. The amplification efficiencies of all qPCR reactions were $90-100 \%$ and $R^{2}$ was between 0.993 and 0.999 .

\section{Community profiling of the nitrifiers and denitrifiers by T-RFLP assay}

The community structure of AOA amoA, AOB amoA, nirK, and $\operatorname{nos} Z$ was determined by T-RFLP analysis using the fluorescently labeled (6-FAM) forward primers. PCR procedure for each gene was the same as described above. PCR products were purified (QiAGEN Gel Extraction Kit, Hilden, Germany) firstly and then were digested with the restriction enzyme listed in Table S1. Terminal restriction fragments (TRFs) were determined with an ABI 3730XL DNA Analyzer and analyzed using Peak Scanner software v1.0 (Applied Biosystems).

\section{Statistical analyses}

The amoA gene copy numbers were log-transformed to meet normality assumptions. Two-way ANOVA was conducted to evaluate effects of soil moisture, $\mathrm{N}$ amendment and their interactions on $\mathrm{pH}$; inorganic $\mathrm{N}$ concentration; total $\mathrm{N}_{2} \mathrm{O}$ emissions; and $a m o A$, nirK, and nosZ gene abundance in SPSS 17.0 (IBM, USA). $P$ value $<0.05$ was believed to be statistically significant. Best of fit modeling of regression between total $\mathrm{N}_{2} \mathrm{O}$ emissions and the abundance of AOB amoA were performed in Sigmaplot (Version 10) using exponential growth equation. Principal coordinate analysis (PCoA) was used to visualize the Bray-Curtis dissimilarity matrices based on the T-RFLP data from soils collected on day 20 of the incubation. Per-mutational multivariate ANOVA (PERMANOVA) was conducted to test the effects of factors and their interactions on the abundances and composition of associated microbial communities, by using the adonis function of the vegan package in R 3.3 software.

\section{Results}

The effects of water and $\mathrm{N}$ amendment on soil properties and total $\mathrm{N}_{2} \mathrm{O}$ emissions

We observed different impacts of water and $\mathrm{N}$ amendment on soil properties in the two soils (Table 1, Fig. 1). In the alluvial soil, $\mathrm{pH}$ remained unchanged around 7.8 after the incubation across all the treatments (Fig. 1a), whereas it was significantly influenced by the addition of water, nitrogen, and their interactions in the red soil (Table 1). In the red soil, $\mathrm{pH}$ at $90 \%$ WFPS was higher than that at 50\% WFPS under ammonium treatment $(P<0.001)$. Ammonium amendment significantly 
Table 1 Summary for the twoway ANOVA on the soil $\mathrm{pH}$, exchangeable $\mathrm{NH}_{4}{ }^{+}-\mathrm{N}$ and $\mathrm{NO}_{3}{ }^{-}-$ $\mathrm{N}$, and total $\mathrm{N}_{2} \mathrm{O}$ emissions for the two factors (soil moisture and $\mathrm{N}$ amendment) and their interactions

\begin{tabular}{lllll}
\hline & $\mathrm{pH}$ & Exchangeable $\mathrm{NH}_{4}{ }^{+}-\mathrm{N}$ & $\mathrm{NO}_{3}{ }^{-}-\mathrm{N}$ & Total $\mathrm{N}_{2} \mathrm{O}$ emissions \\
\hline $\begin{array}{llll}\text { Alluvial soil } \\
\quad\end{array}$ & & & \\
Water & 0.951 & 0.498 & 0.741 & $<0.001$ \\
$\quad$ Nitrogen & 0.413 & 0.18 & $<0.001$ & $<0.001$ \\
Water $\times$ nitrogen & 0.376 & 0.523 & 0.563 & $<0.001$ \\
Red soil & & & & \\
Water & $<0.001$ & $<0.001$ & $<0.001$ & $<0.001$ \\
Nitrogen & $<0.001$ & $<0.001$ & $<0.001$ & $<0.001$ \\
Water $\times$ nitrogen & $<0.001$ & $<0.001$ & 0.028 & $<0.001$ \\
\hline
\end{tabular}

$P$ values $(P<0.05)$ are indicated in italics

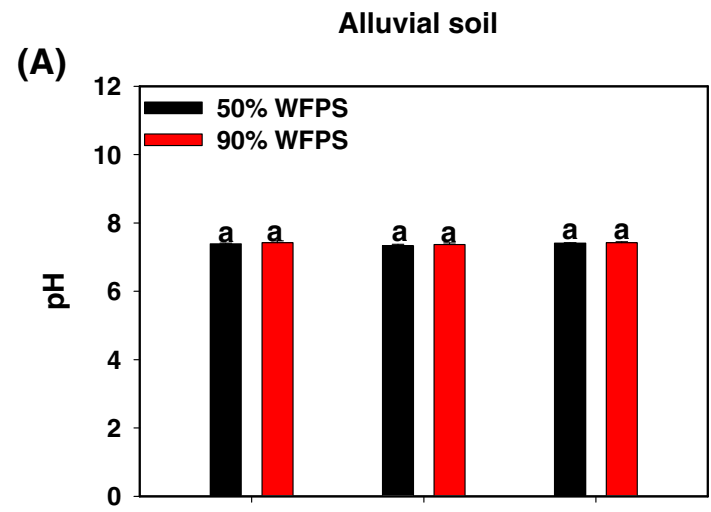

(B)

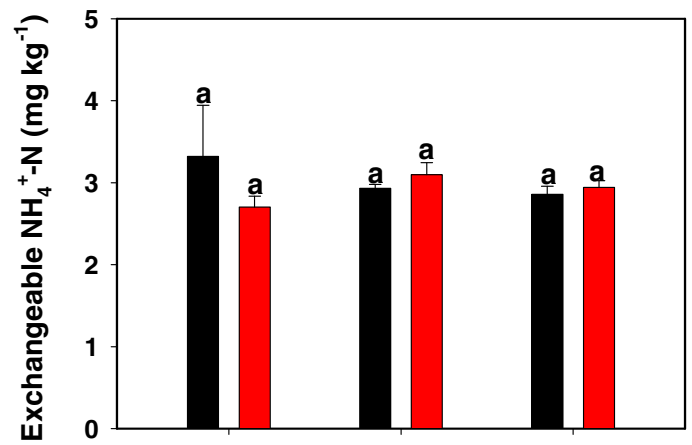

(C)

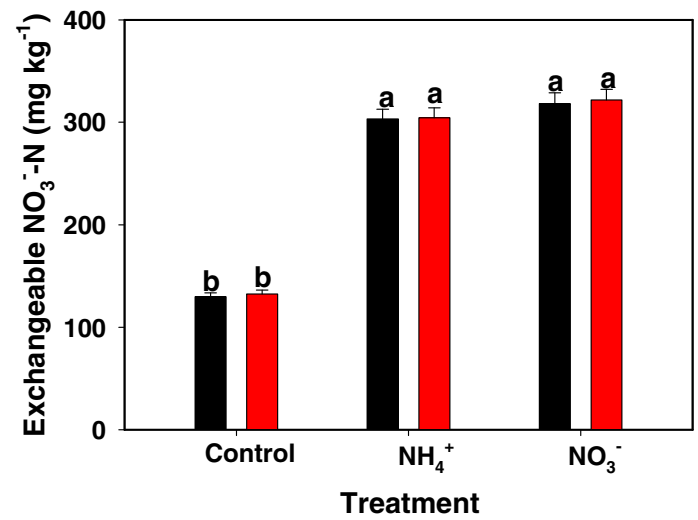

Fig. 1 Effects of soil moisture and $\mathrm{N}$ amendment on soil $\mathrm{pH}$ and exchangeable $\mathrm{NH}_{4}{ }^{+}-\mathrm{N}$ and $\mathrm{NO}_{3}{ }^{-}-\mathrm{N}$ content in the alluvial soil $(\mathbf{a}-\mathbf{c})$ and the red soil $(\mathbf{d}-\mathbf{f})$. Error bars are standard errors $(n=3)$.
(D)

Red soil

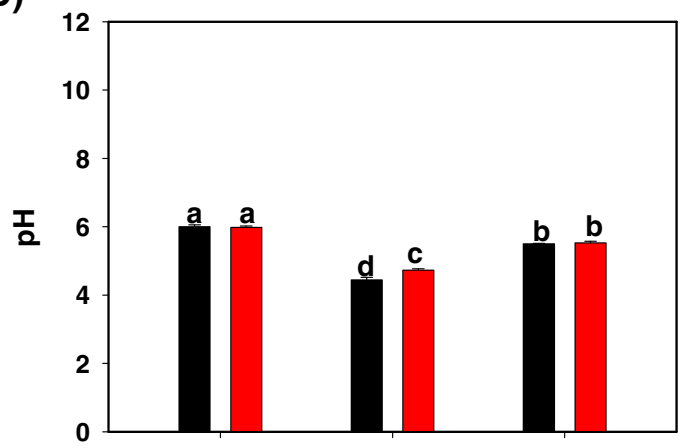

(E)

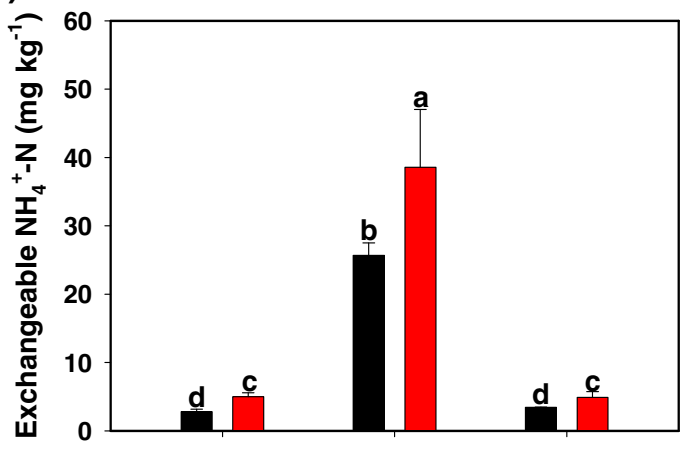

(F)

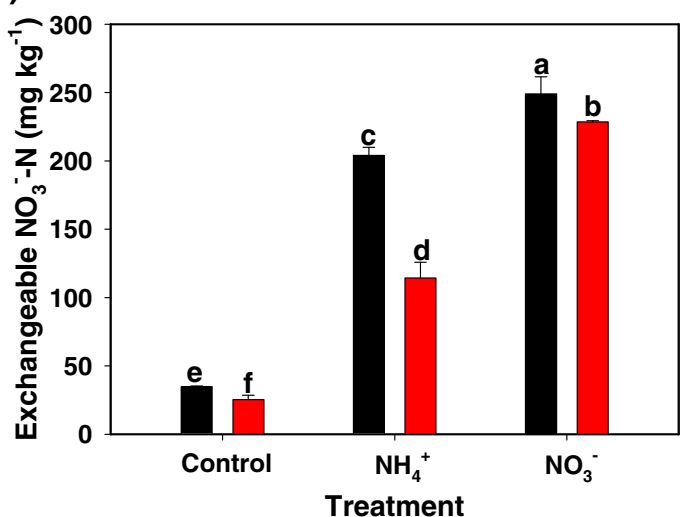

Statistically significant differences among treatments are represented by different lowercase letters $(P<0.05)$ 
reduced $\mathrm{pH}(P<0.001)$, which was much lower than that in the $\mathrm{NO}_{3}{ }^{-}$-treated soils $(P<0.001)$ (Fig. 1d).

Soil moisture showed different effects on exchangeable $\mathrm{NH}_{4}{ }^{+}-\mathrm{N}$ and $\mathrm{NO}_{3}{ }^{-}-\mathrm{N}$ concentration in the two soils (Table 1, Fig. 1). In the alluvial soil, soil moisture change did not affect exchangeable $\mathrm{NH}_{4}{ }^{+}-\mathrm{N}$ and $\mathrm{NO}_{3}{ }^{-}-\mathrm{N}$ concentration (Fig. 1b, c). However, $\mathrm{NO}_{3}{ }^{-}-\mathrm{N}$ concentration was markedly influenced by $\mathrm{N}$ amendment $(P<0.001)$ (Table 1, Fig. 1c). In the red soil, high soil moisture (90\% WFPS) led to higher exchangeable $\mathrm{NH}_{4}{ }^{+}-\mathrm{N}$ concentration compared to low moisture level $(50 \%$ WFPS) (Fig. 1e), while $\mathrm{NO}_{3}{ }^{-}-\mathrm{N}$ concentration was lower at $90 \%$ WFPS than at 50\% WFPS (Fig. 1f).

Total $\mathrm{N}_{2} \mathrm{O}$ emissions were significantly affected by soil moisture, $\mathrm{N}$ fertilization, and their interactions (Table 1). In Fig. 2, we found that $\mathrm{N}_{2} \mathrm{O}$ emissions were higher at $90 \%$ WFPS than that at $50 \%$ WFPS in the two soils. There were also significant differences in total $\mathrm{N}_{2} \mathrm{O}$ production in the two soils under $\mathrm{N}$ treatments though soil moisture was kept for the same, with higher values in $\mathrm{NH}_{4}{ }^{+}$-treated soils than in $\mathrm{NO}_{3}{ }^{-}-$ treated soils.

\section{The effects of water and $\mathrm{N}$ amendment on abundance of nitrifiers and denitrifiers}

For nitrifiers in the two soils, AOA amoA abundance was not affected by the changed soil water content (Table 2, Fig. 3a). Soil moisture significantly affected AOB amoA abundance with 90\% WFPS soil containing 1.5-2 times as many AOB amoA copies as 50\% WFPS in both soils (Fig. 3b, f). AOA $a m o A$ abundance was not strongly altered by $\mathrm{N}$ addition in the alluvial soil, whereas $\mathrm{N}$ amendment reduced it in both $\mathrm{NH}_{4}{ }^{+}$ and $\mathrm{NO}_{3}{ }^{-}$treatments in red soil (Fig. 3e). The population size of AOB was higher in the $\mathrm{NH}_{4}{ }^{+}$treatment than in other treatments in the two soils (Fig. 3b, f).

For denitrifiers, enhanced soil moisture markedly increased nirK abundance but not nos $Z$ abundance in the alluvial soil
(Fig. 3c, d). Ammonium addition significantly increased the nirK abundance while $\mathrm{NO}_{3}{ }^{-}$amendment did not influence it compared to the control (Fig. 3c). NosZ abundance did not respond to $\mathrm{NH}_{4}{ }^{+}$or $\mathrm{NO}_{3}{ }^{-}$fertilizers in this soil (Fig. 3d). In the red soil, nirK abundance greatly increased with the soil moisture increased from 50 to $90 \%$ WFPS (Fig. 3g). The application of $\mathrm{NH}_{4}{ }^{+}$significantly reduced nirK and nos $Z$ abundance, which was unchanged in the $\mathrm{NO}_{3}{ }^{-}$-related treatments (Fig. 3g, h).

The regression analysis revealed that total $\mathrm{N}_{2} \mathrm{O}$ emissions were significantly correlated with $\mathrm{AOB}$ amoA abundance in the alluvial soil $\left(R^{2}=0.98, P<0.001\right)($ Fig. $4 \mathrm{a})$ and red soil $\left(R^{2}=0.65, P<0.001\right)$ (Fig. 4b). However, other functional genes were not correlated with total $\mathrm{N}_{2} \mathrm{O}$ emissions in the two soils.

\section{The effects of water and $\mathrm{N}$ amendment on nitrifier and denitrifier community composition}

Soil moisture affected AOA amoA community composition in the alluvial soil, whereas there was no effect of $\mathrm{N}$ treatment on AOA amoA community composition (Table 3, Fig. 5a). In the red soil, PERMANOVA analysis revealed that AOA amoA community composition was influenced by soil moisture, $\mathrm{N}$ amendment, and their interactions (Table 3), which was further supported by PCoA (Fig. 5e). AOB amoA community composition was significantly affected by $\mathrm{NH}_{4}{ }^{+}$addition and a pair-wise comparison revealed a significant difference between control and $\mathrm{NH}_{4}{ }^{+}$treatment in both soils (Table 3; Fig. 5b, f). A pair-wise PERMANOVA test, however, delivered no significant difference between control and $\mathrm{NO}_{3}{ }^{-}$-treated AOB amoA community composition in both soils (Table 3).

Soil moisture and $\mathrm{N}$ amendment did not influence denitrifier (nirK and nos Z) community composition in the alluvial soil (Table 3; Fig. 5c, d). In contrary, soil moisture and $\mathrm{N}$
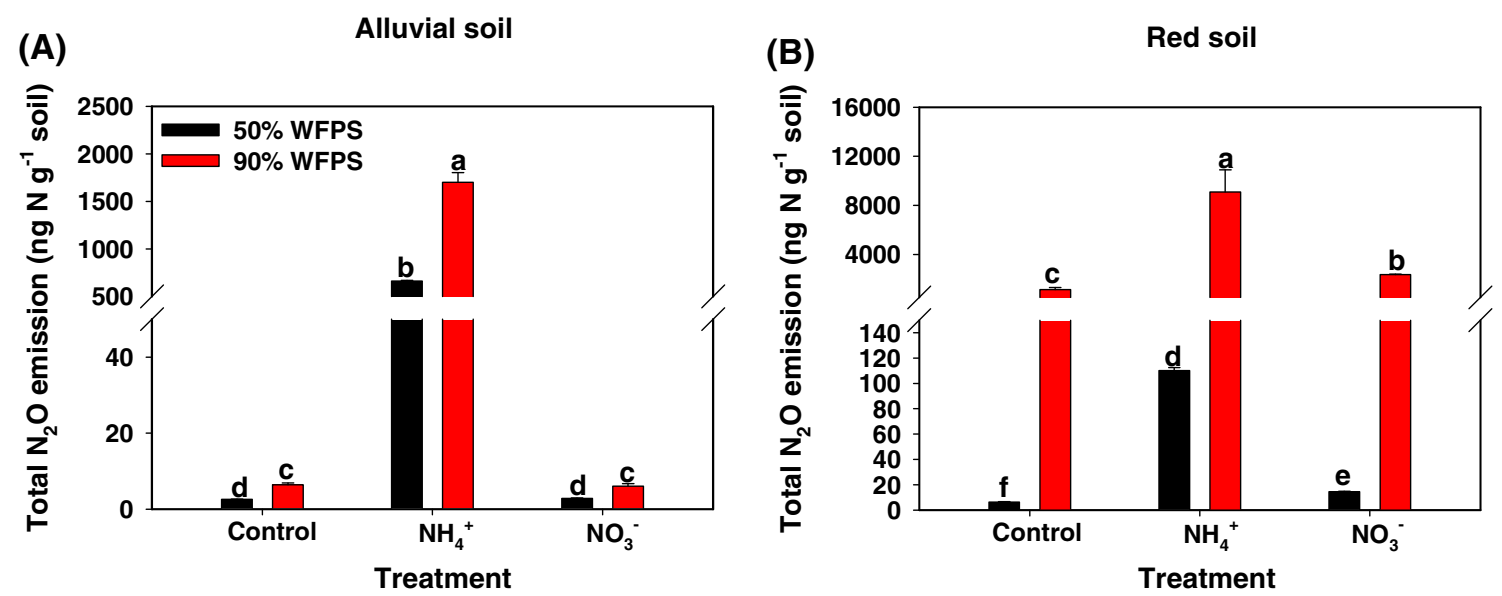

Fig. 2 Effects of soil moisture and $\mathrm{N}$ amendment on total $\mathrm{N}_{2} \mathrm{O}$ emissions for the entire experiment (20 days) in the alluvial soil (a) and the red soil (b). Error bars are standard errors $(n=3)$. Statistically significant differences among treatments are represented by different lowercase letters $(P<0.05)$ 
Table 2 Summary for the twoway ANOVA on AOA amoA, AOB amoA, nirK, and nos $Z$ gene abundance for the two factors (soil moisture and $\mathrm{N}$ amendment) and their interactions

\begin{tabular}{lcllc}
\hline & $\begin{array}{l}\text { Abundance of AOA } \\
\text { amoA }\end{array}$ & $\begin{array}{l}\text { Abundance of } \\
\text { AOB amoA }\end{array}$ & $\begin{array}{l}\text { Abundance } \\
\text { of nirK }\end{array}$ & Abundance of $n$ osZ \\
\hline Alluvial soil & & & & \\
$\quad$ Water & 0.751 & $<0.001$ & $<0.001$ & 0.529 \\
Nitrogen & 0.793 & $<0.001$ & 0.007 & 0.918 \\
Water $\times$ nitrogen & 0.554 & 0.059 & 0.016 & 0.698 \\
Red soil & 0.354 & & $<0.001$ & 0.076 \\
Water & $<0.001$ & $<0.001$ & $<0.001$ & $<0.001$ \\
Nitrogen & 0.692 & 0.751 & 0.002 & 0.822 \\
Water $\times$ nitrogen & & & $<01$ & \\
\hline
\end{tabular}

$P$ values $(P<0.05)$ are indicated in italics addition and their interactions significantly affected nir $K$ and nos $Z$ community composition in the red soil and a pair-wise comparison showed obvious difference among the treatments (Table 3; Fig. 5g, h).

\section{Discussion}

Our results showed that soil moisture was a key factor for $\mathrm{N}_{2} \mathrm{O}$ emissions from $\mathrm{N}$-treated soils, and higher $\mathrm{N}_{2} \mathrm{O}$ emissions were observed at high soil moisture than at low soil moisture in both soils. Normally, the soil becomes more anaerobic as soil water content increased, leading to high $\mathrm{N}_{2} \mathrm{O}$ emissions from denitrification. Obviously, the higher $\mathrm{N}_{2} \mathrm{O}$ production at 90\% WFPS indicated that both soils did not become completely anaerobic at high soil water content because complete denitrification can lead to the conversion of $\mathrm{N}_{2} \mathrm{O}$ to $\mathrm{N}_{2}$, decreasing $\mathrm{N}_{2} \mathrm{O}$ production (Smith et al. 1998; Zhu et al. 2013a). We observed higher $\mathrm{N}_{2} \mathrm{O}$ emissions in soils treated with ammonium than in soils treated with nitrate, especially under high soil water content level (90\% WFPS). These results indicate that $\mathrm{N}_{2} \mathrm{O}$ emission process is regulated by soil moisture and $\mathrm{N}$ fertilizer type (Zhu et al. 2013b; Minick et al. 2016). In addition, we also observed AOB abundance was significantly correlated to total $\mathrm{N}_{2} \mathrm{O}$ emissions (Fig. 4). These findings together emphasized that ammonia oxidation (nitrifier nitrification and nitrifier denitrification) was the predominant pathway for $\mathrm{N}_{2} \mathrm{O}$ emissions in this study. In accordance, Zhu et al. (2013a, b) demonstrated that nitrifier denitrification is a significant source of $\mathrm{N}_{2} \mathrm{O}$ at high soil moisture or low $\mathrm{O}_{2}$ availability in soils. The nitrifier denitrification is conducted by $\mathrm{AOB}$, which used $\mathrm{NO}_{2}{ }^{-}$rather than $\mathrm{O}_{2}$ as a terminal electron acceptor, reducing $\mathrm{NO}_{2}{ }^{-}$to $\mathrm{N}_{2} \mathrm{O}$ (Wrage et al. 2001). Nitrification and denitrification have optima under different environmental conditions, and they can appear simultaneously in different microsites (Butterbach-Bahl et al. 2013). The sandy loam in the alluvial soil, being well aerated, poor in SOC content, and with relatively high $\mathrm{pH}$, is likely to provide more favorable conditions for nitrification (Wan et al.
2009; Huang et al. 2014a). However, the silty clay loam in the red soil might become more anoxic at higher soil water content than sandy loam soil in the alluvial soil (Szukics et al. 2010). Therefore, higher $\mathrm{N}_{2} \mathrm{O}$ emissions in high soil moisture that depended on ammonium addition in the red soil might derive from nitrification and denitrification because ammonia oxidation could produce large amount of nitrate, which could be used as substrate for denitrification.

The abundances of nitrifiers in the alluvial soil and red soil responded distinctively to soil moisture and $\mathrm{N}$ addition, suggesting $\mathrm{N}$ transformation processes varied with different soil types. In both soils, increased soil moisture obviously stimulated the growth of $\mathrm{AOB}$ rather than $\mathrm{AOA}$, indicating that soil moisture was an important factor influencing AOB abundance. Similarly, Chen et al. (2013b) showed that precipitation significantly increased the abundance of AOB, while AOA abundance kept stable in the Inner Mongolia grassland. Di et al. (2014) also observed that the population size of AOB increased with increasing soil water content (from 60 to $130 \%$ WHC) in a grassland soil. We speculated that increased soil moisture could promote diffusion and transport of nutrients in soils, providing microorganisms with key substrates such as $\mathrm{NH}_{3}, \mathrm{NO}_{3}{ }^{-}$, and soluble organic $\mathrm{C}$ (Blagodatsky and Smith 2012). In the $\mathrm{N}$ treatments, ammonium amendment significantly enhanced AOB abundance in the alluvial soil and red soil. However, ammonium addition did not have obvious effect on the abundance of AOA in the alluvial soil, but reduced it in the red soil. The AOA abundance might have been reduced by low $\mathrm{pH}$ caused by the application of ammonium fertilizer in the red soil, since it was reported previously that AOA abundance was positively correlated with soil $\mathrm{pH}$ (3.78.7) at 47 sites across the UK (Gubry-Rangin et al. 2011). Although the negative effect of $\mathrm{N}$ fertilization on the AOA abundance has been frequently reported before (Di et al. 2014; Wang et al. 2016b), the effect of $\mathrm{N}$ form on it is still equivocal and has rarely been attributed to nitrate application. In the study, the strongly negative effect of nitrate addition on AOA abundance in the red soil indicated that nitrate was also the effective $\mathrm{N}$ form that inhibited the growth of AOA in this 
(A)

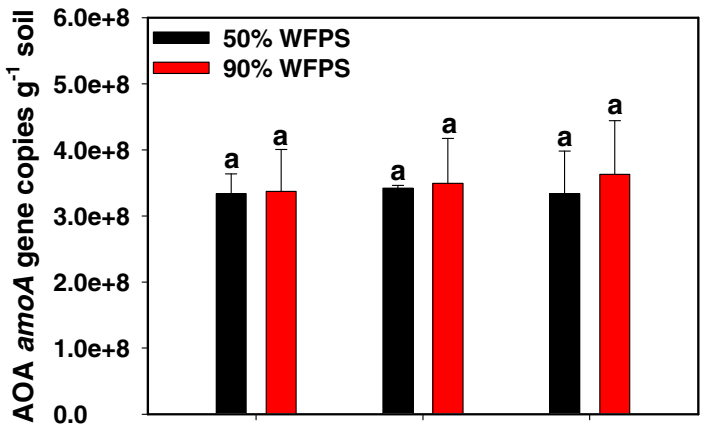

(B)

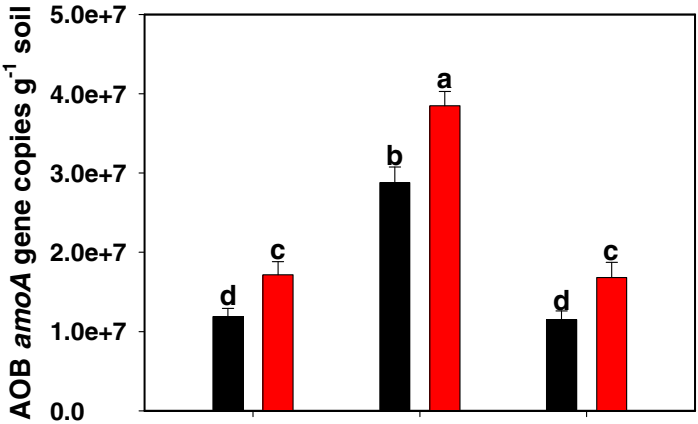

(C)

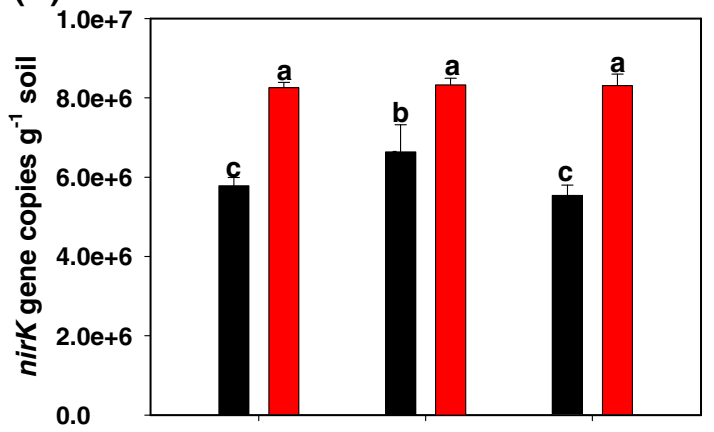

(D)

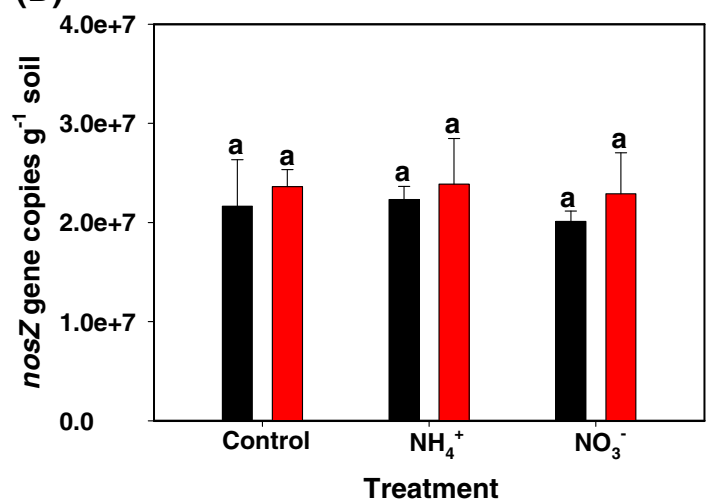

Fig. 3 Effects of soil moisture and $\mathrm{N}$ amendment on the abundance of AOA amoA, AOB amoA, nirK, and nos $Z$ genes in the alluvial soil (a-d) and the red soil $(\mathbf{e}-\mathbf{h})$. Error bars are standard errors $(n=3)$. Statistically

soil. Similar result was reported recently in Inner Mongolia grassland soil (Ying et al. 2017). Further study needs to be
(E)

Red soil

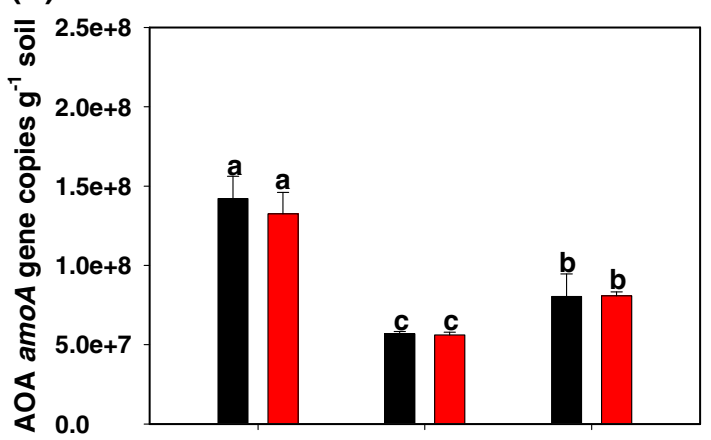

(F)

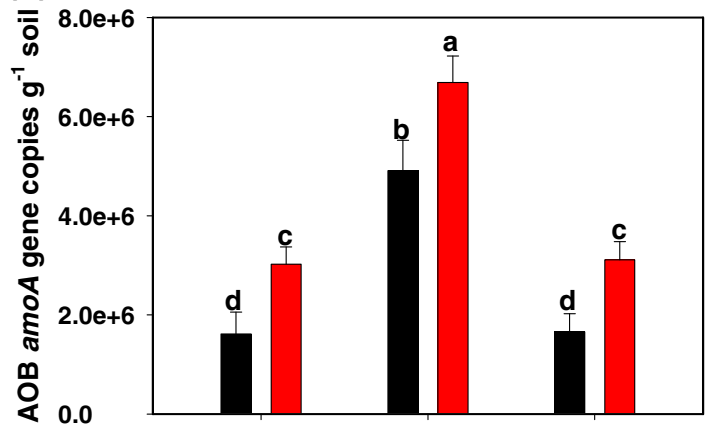

(G)

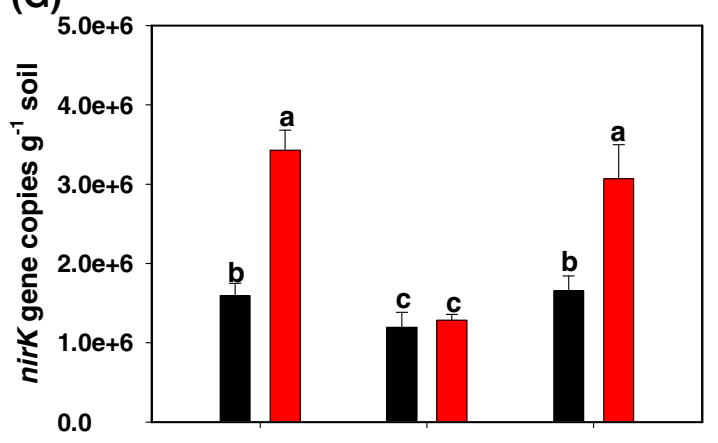

(H)

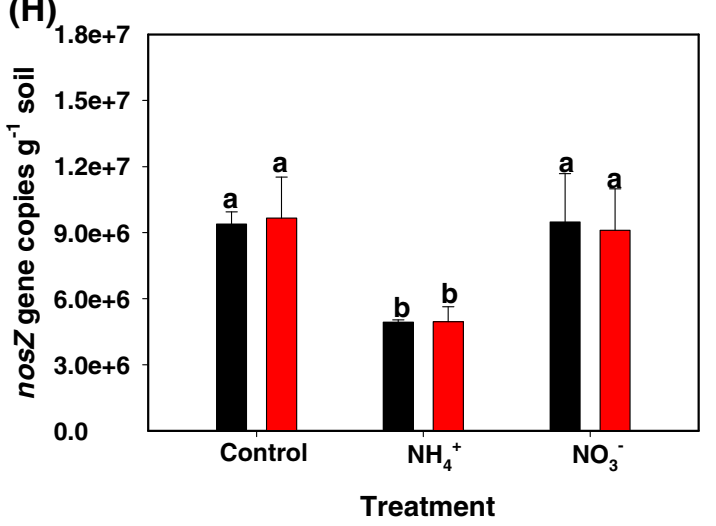

significant differences among treatments are represented by different lowercase letters $(P<0.05)$

carried out to unravel inhibitive mechanisms of nitrate on AOA growth. 

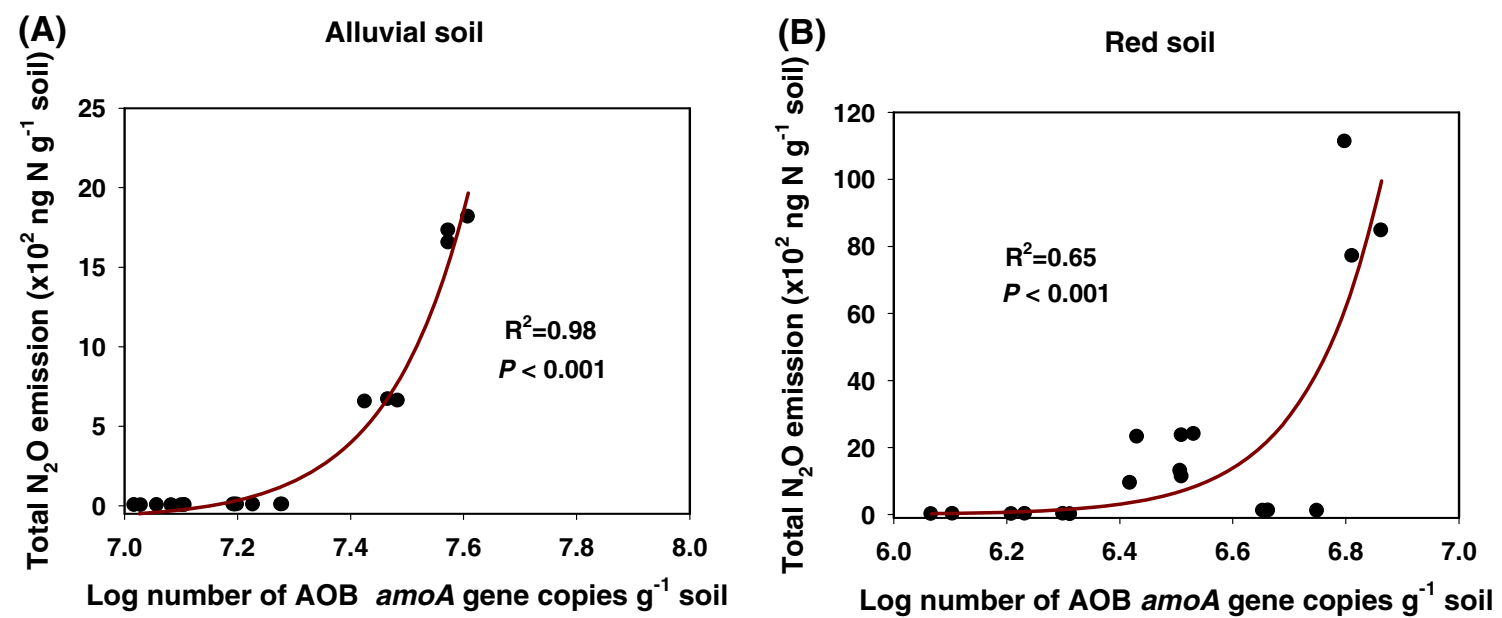

Fig. 4 Relationships of total $\mathrm{N}_{2} \mathrm{O}$ emissions with $\mathrm{AOB}$ amoA abundance in the alluvial soil (a) and the red soil (b)

In the present study, soil moisture significantly changed AOA community composition in the alluvial soil and red soil, while no similar effect was observed on AOB community composition, showing that soil moisture was a crucial determinant of AOA community composition. The significant

Table 3 Results of PERMANOVA for testing the effects of soil moisture, $\mathrm{N}$ amendment, and their interactions on ammonia oxidizer and denitrifier community composition in the alluvial soil and red soil

\begin{tabular}{|c|c|c|c|c|}
\hline & AOA amoA & AOB amoA & $\operatorname{nirK}$ & $\operatorname{nos} Z$ \\
\hline \multicolumn{5}{|l|}{ Alluvial soil } \\
\hline Water & $<0.001$ & 0.144 & 0.103 & 0.254 \\
\hline Nitrogen & 0.477 & $<0.001$ & 0.544 & 0.114 \\
\hline Water $\times$ nitrogen & 0.243 & 0.404 & 0.058 & 0.329 \\
\hline \multicolumn{5}{|l|}{$50 \%$ WFPS } \\
\hline Control $\times \mathrm{NH}_{4}{ }^{+}$ & 0.451 & $<0.001$ & 0.403 & 0.531 \\
\hline Control $\times \mathrm{NO}_{3}^{-}$ & 0.226 & 0.129 & 0.676 & 0.244 \\
\hline $\mathrm{NH}_{4}^{+} \times \mathrm{NO}_{3}^{-}$ & 0.821 & $<0.001$ & 0.658 & 0.561 \\
\hline \multicolumn{5}{|l|}{$90 \%$ WFPS } \\
\hline Control $\times \mathrm{NH}_{4}^{+}$ & 0.601 & 0.004 & 0.062 & 0.852 \\
\hline Control $\times \mathrm{NO}_{3}^{-}$ & 0.221 & 0.297 & 0.182 & 0.632 \\
\hline $\mathrm{NH}_{4}^{+} \times \mathrm{NO}_{3}^{-}$ & 0.168 & 0.005 & 0.83 & 0.302 \\
\hline \multicolumn{5}{|l|}{ Red soil } \\
\hline Water & $<0.001$ & 0.124 & $<0.001$ & $<0.001$ \\
\hline Nitrogen & $<0.001$ & $<0.001$ & $<0.001$ & $<0.001$ \\
\hline Water $\times$ nitrogen & $<0.001$ & 0.113 & $<0.001$ & $<0.001$ \\
\hline \multicolumn{5}{|l|}{$50 \%$ WFPS } \\
\hline Control $\times \mathrm{NH}_{4}^{+}$ & $<0.001$ & $<0.001$ & 0.002 & 0.003 \\
\hline Control $\times \mathrm{NO}_{3}^{-}$ & $<0.001$ & 0.335 & $<0.001$ & 0.004 \\
\hline $\mathrm{NH}_{4}^{+} \times \mathrm{NO}_{3}^{-}$ & 0.003 & $<0.001$ & 0.004 & 0.004 \\
\hline \multicolumn{5}{|l|}{ 90\%WFPS } \\
\hline Control $\times \mathrm{NH}_{4}^{+}$ & $<0.001$ & $<0.001$ & 0.005 & 0.005 \\
\hline Control $\times \mathrm{NO}_{3}^{-}$ & 0.009 & 0.405 & 0.012 & 0.003 \\
\hline $\mathrm{NH}_{4}^{+} \times \mathrm{NO}_{3}^{-}$ & $<0.001$ & $<0.001$ & 0.004 & 0.007 \\
\hline
\end{tabular}

$P$ values $(P<0.05)$ are indicated in italics response in AOA community composition to soil moisture was similar as other studies (Gleeson et al. 2010; Szukics et al. 2012). Both groups of AOA and AOB have distinct physiological characteristics and ecological niches in response to soil water availability. There appeared to be two dissimilar populations of AOA in the soils, one grew under oxic conditions and the other grew under sub-oxic conditions. In the $\mathrm{N}$ treatment, the AOB community composition was significantly altered by ammonium addition in both soils. However, our result was inconsistent with previous study of Avrahami et al. (2002) who reported that agricultural soils did not show any AOB community shifts under ammonium treatment with 4-6 weeks of incubation. This inconsistency might be attributed to higher ammonium level in our study, which could promote the growth of AOB in soils (Jia and Conrad 2009; Cui et al. 2013). AOA community composition remained unchanged after $\mathrm{N}$ amendment in the alluvial soil, while was altered by it in the red soil. AOB is more sensitive than AOA in response to $\mathrm{N}$ fertilization in alkaline soil while AOA is more sensitive to $\mathrm{N}$ fertilization than AOB in acidic red soil. This is in agreement with Chen et al. (2010) suggesting that soil type is most likely another key factor in affecting ammonia oxidizer community composition under the $\mathrm{N}$ treatment.

Water and $\mathrm{N}$ amendment have a significant impact on the abundances of denitrifiers (nirK and nosZ) in the tested soils. Increasing soil water content reduces gaseous diffusion rates, limiting oxygen which is favorable for the growth of denitrifiers (Blagodatsky and Smith 2012), as the nirK abundance increased with enhanced soil moisture. However, the nos $Z$ abundance remained stable between the soil water treatments which implied that the soil condition was less anaerobic because $\mathrm{N}_{2} \mathrm{O}$ reductase (NOS) was the most sensitive to $\mathrm{O}_{2}$ inhibition (Knowles 1982; Morley et al. 2008). The increased nirK abundance in the alluvial soil after the addition of ammonium was in line with earlier reports suggesting that application of urine increased the population size of nirK (Hamonts 

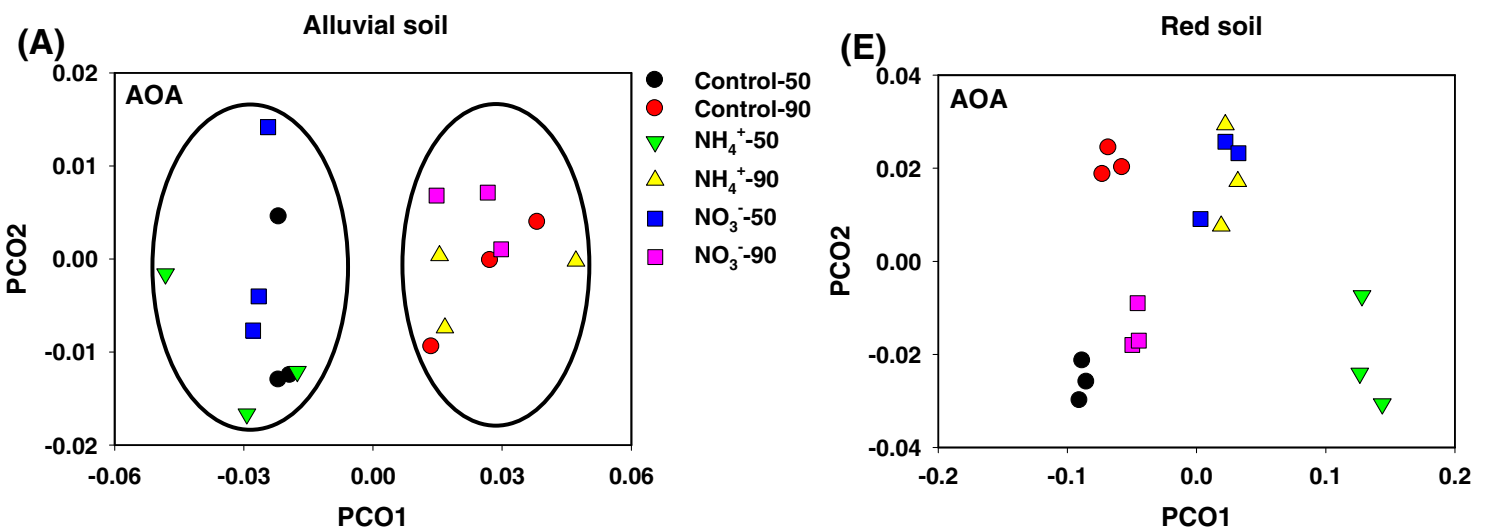

(B)

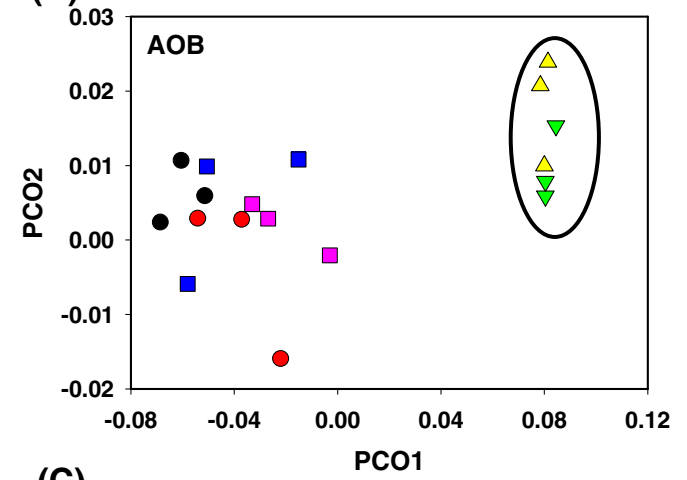

(F)

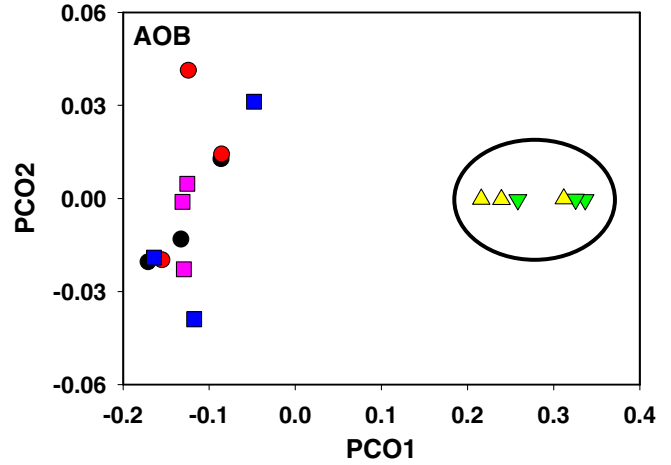

(C)

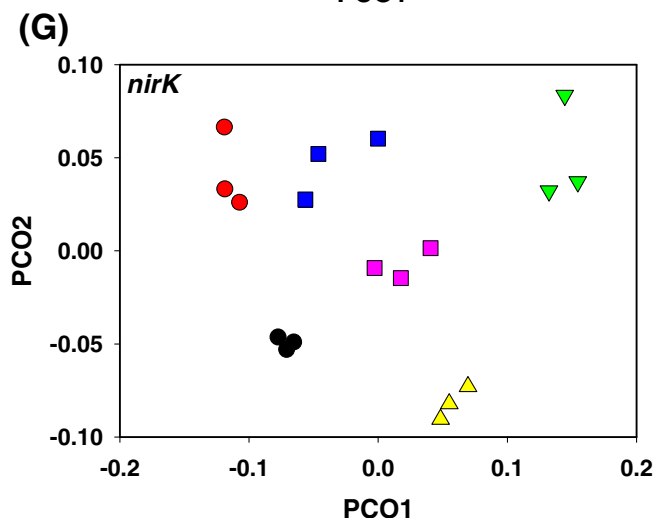

(D)

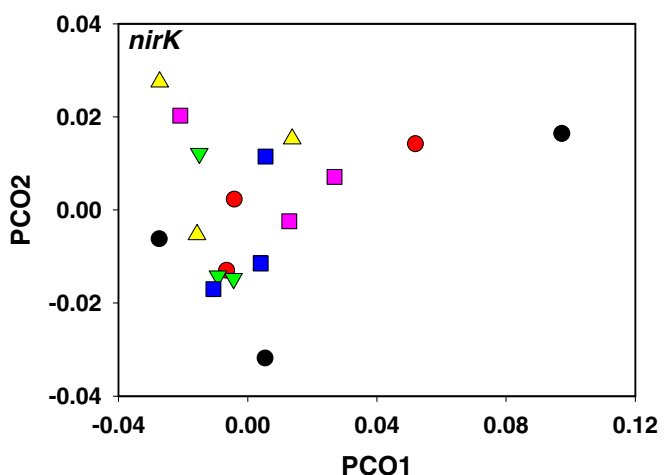

(H)
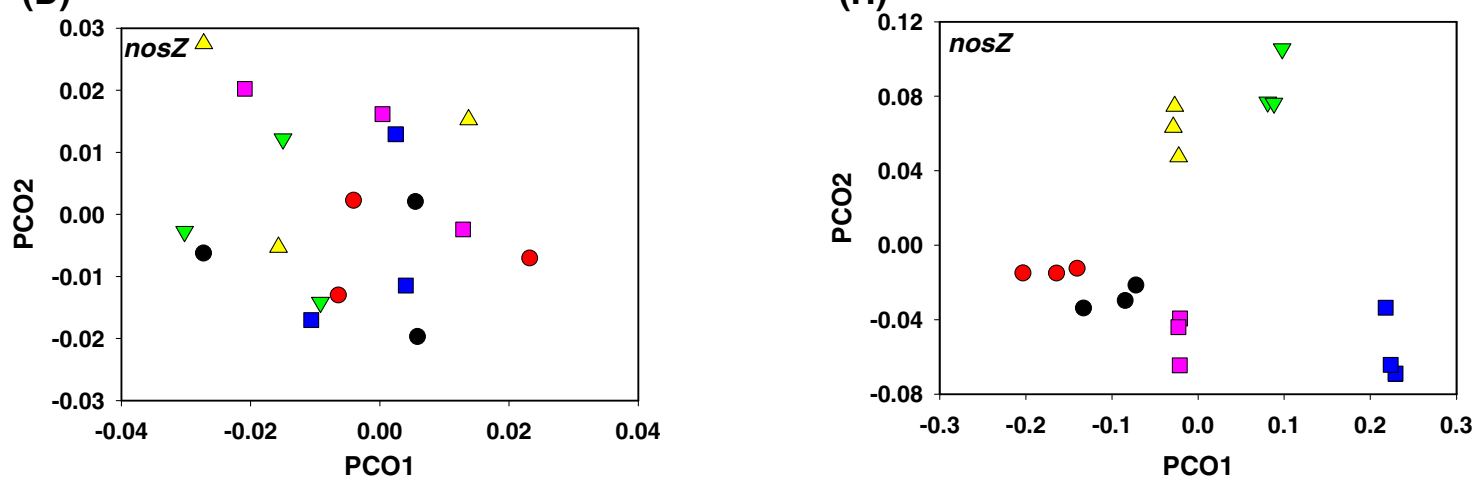

Fig. 5 Principal coordinate analysis (PCoA) of AOA amoA, AOB amoA, nirK, and nos $Z$ gene community profiles in response to $\mathrm{NH}_{4}{ }^{+}$and $\mathrm{NO}_{3}{ }^{-}$and without $\mathrm{N}$ addition in the alluvial soil $(\mathbf{a}-\mathbf{d})$ and the red soil $(\mathbf{e}-\mathbf{h})$

et al. 2013; Di et al. 2014). Overall, the changes of the nirK abundance were similar to that of $\mathrm{AOB}$ in the alluvial soil (Fig. 3b, c). Genome analysis suggested that most of AOB communities contained the nirK gene which was related to the pathway known as nitrifier denitrification (Shaw et al. 2006; Kim et al. 2010). However, in the red soil, the 
abundances of $\operatorname{nir} K$ and $\operatorname{nos} Z$ genes decreased under the ammonium treatment, implying the response of denitrifying genes to ammonium addition varied depending on soil properties. Soil $\mathrm{pH}$ was obviously reduced in the ammoniumtreated soils in comparison with the control after incubation which could significantly inhibit the growth of denitrifiers (Čuhel et al. 2010; Bakken et al. 2012; Huang et al. 2014b). A notable discovery was that the community composition of nirK and nosZ responded differently to the water and $\mathrm{N}$ amendment in the two soils. Denitrifier community composition was less affected in response to water and $\mathrm{N}$ treatments in the alluvial soil, whereas clearly changed in the red soil. The distinct responses of denitrifier community composition to water and $\mathrm{N}$ amendment in the alluvial soil and red soil could be ascribed to soil type.

\section{Conclusion}

In conclusion, our study demonstrates dissimilar responses of $\mathrm{N}_{2} \mathrm{O}$ emissions and associated microbes to $\mathrm{N}$ addition at altered soil moisture levels in the two soils. Total $\mathrm{N}_{2} \mathrm{O}$ emissions induced by increased soil water content and $\mathrm{N}$ addition in the red soil were much higher than that in the alluvial soil. Increased soil moisture increased $\mathrm{AOB}$ and nirK abundance in the two soils. Soil $\mathrm{NH}_{4}{ }^{+}$addition increased $\mathrm{AOB}$ and nirK abundance in the alluvial soil, but decreased nirK and nos $Z$ abundance in the red soil. Different soil types could result in differences in soil SOC, soil texture, and $\mathrm{pH}$, which may influence $\mathrm{N}_{2} \mathrm{O}$ emissions and the growth of associated functional guilds in soils. Our results suggest that caution should be taken when applying $\mathrm{N}$ fertilization into high-moisture soils for mitigating $\mathrm{N}_{2} \mathrm{O}$ emissions in the agricultural management.

Acknowledgements This work was supported by the Strategic Priority Research Program of the Chinese Academy of Sciences (XDB15020200) and by the Natural Science Foundation of China (41322007 and 41371265).

\section{References}

Avrahami S, Conrad R, Braker G (2002) Effect of soil ammonium concentration on $\mathrm{N}_{2} \mathrm{O}$ release and on the community structure of ammonia oxidizers and denitrifiers. Appl Environ Microb 68:56855692

Baggs EM (2011) Soil microbial sources of nitrous oxide: recent advances in knowledge, emerging challenges and future direction. Curr Opin Env Sust 3:321-327

Bakken LR, Bergaust L, Liu BB, Frostegard A (2012) Regulation of denitrification at the cellular level: a clue to the understanding of $\mathrm{N}_{2} \mathrm{O}$ emissions from soils. Philos Trans R Soc Lond Ser B Biol Sci 367:1226-1234

Banerjee S, Helgason B, Wang LF, Winsley T, Ferrari BC, Siciliano SD (2016) Legacy effects of soil moisture on microbial community structure and $\mathrm{N}_{2} \mathrm{O}$ emissions. Soil Biol Biochem 95:40-50
Bateman EJ, Baggs EM (2005) Contributions of nitrification and denitrification to $\mathrm{N}_{2} \mathrm{O}$ emissions from soils at different water-filled pore space. Bio Fertil Soils 41:379-388

Blagodatsky S, Smith P (2012) Soil physics meets soil biology: towards better mechanistic prediction of greenhouse gas emissions from soil. Soil Biol Biochem 47:78-92

Butterbach-Bahl K, Baggs EM, Dannenmann M, Kiese R, ZechmeisterBoltenstern S (2013) Nitrous oxide emissions from soils: how well do we understand the processes and their controls? Philos T R Soc B 368

Chapuis-Lardy L, Wrage N, Metay A, CHOTTE JL, Bernoux M (2007) Soils, a sink for $\mathrm{N}_{2} \mathrm{O}$ ? A review. Glob Chang Biol 13:1-17

Chen X, Zhang LM, Shen JP, Xu ZH, He JZ (2010) Soil type determines the abundance and community structure of ammonia-oxidizing bacteria and archaea in flooded paddy soils. J Soils Sediments 10:1510 1516

Chen HH, Li X, Hu F, Shi W (2013a) Soil nitrous oxide emissions following crop residue addition: a meta-analysis. Glob Chang Biol 19: 2956-2964

Chen YL, Xu ZW, Hu HW, Hu YJ, Hao ZP, Jiang Y, Chen BD (2013b) Responses of ammonia-oxidizing bacteria and archaea to nitrogen fertilization and precipitation increment in a typical temperate steppe in Inner Mongolia. Appl Soil Ecol 68:36-45

Cheng Y, Wang J, Wang SQ, Zhang JB, Cai ZC (2014) Effects of soil moisture on gross $\mathrm{N}$ transformations and $\mathrm{N}_{2} \mathrm{O}$ emission in acid subtropical forest soils. Bio Fertil Soils 50:1099-1108

Corre MD, Pennock DJ, Van Kessel C, Kirkelliott D (1999) Estimation of annual nitrous oxide emissions from a transitional grassland-forest region in Saskatchewan, Canada. Biogeochemistry 44:29-49

Čuhel J, Miloslav Š, Ronnie JL, David B (2010) Insights into the effect of soil $\mathrm{pH}$ on $\mathrm{N}_{2} \mathrm{O}$ and $\mathrm{N}_{2}$ emissions and denitrifier community size and activity. Appl Environ Microbiol 76:1870-1878

Cui P, Fan F, Yin C, Li Z, Song A, Wan Y, Liang Y (2013) Urea- and nitrapyrin-affected $\mathrm{N}_{2} \mathrm{O}$ emission is coupled mainly with ammonia oxidizing bacteria growth in microcosms of three typical Chinese arable soils. Soil Biol Biochem 66:214-221

Davidson EA (2009) The contribution of manure and fertilizer nitrogen to atmospheric nitrous oxide since 1860. Nat Geosci 2:659-662

Del Prado A, Merino P, Estavillo JM, Pinto M, Gonzalez-Murua C (2006) $\mathrm{N}_{2} \mathrm{O}$ and $\mathrm{NO}$ emissions from different $\mathrm{N}$ sources and under a range of soil water contents. Nutr Cycl Agroecosys 74:229-243

Di HJ, Cameron KC, Podolyan A, Robinson A (2014) Effect of soil moisture status and a nitrification inhibitor, dicyandiamide, on ammonia oxidizer and denitrifier growth and nitrous oxide emissions in a grassland soil. Soil Biol Biochem 73:59-68

Giles ME, Morley NJ, Baggs EM, Daniell TJ (2012) Soil nitrate reducing processes-drivers, mechanisms for spatial variation, and significance for nitrous oxide production. Front Microbiol 3:407. doi:10.3389/ fmicb.2012.00407

Gleeson DB, Muller C, Banerjee S, Ma W, Siciliano SD, Murphy DV (2010) Response of ammonia oxidizing archaea and bacteria to changing water filled pore space. Soil Biol Biochem 42:1888-1891

Goldberg SD, Gebauer G (2009) Drought turns a central European Norway spruce forest soil from an $\mathrm{N}_{2} \mathrm{O}$ source to a transient $\mathrm{N}_{2} \mathrm{O}$ sink. Glob Chang Biol 15:850-860

Gubry-Rangin C, Hai B, Quince C, Engel M, Thomson BC, James P, Schloter M, Griffiths RI, Prosser JI, Nicol GW (2011) Niche specialization of terrestrial archaeal ammonia oxidizers. Proc Natl Acad Sci U S A 108:21206-21211

Hamonts K, Balaine N, Moltchanova E, Beare M, Thomas S, Wakelin SA (2013) Influence of soil bulk density and matric potential on microbial dynamics, inorganic $\mathrm{N}$ transformations, $\mathrm{N}_{2} \mathrm{O}$ and $\mathrm{N}_{2}$, fluxes following urea deposition. Soil Biol Biochem 65:1-11

Hu HW, Chen D, He JZ (2015a) Microbial regulation of terrestrial nitrous oxide formation: understanding the biological pathways for prediction of emission rates. FEMS Microbiol Rev 39:729-749 
Hu HW, Macdonald CA, Trivedi P, Holmes B, Bodrossy L, He JZ, Singh BK (2015b) Water addition regulates the metabolic activity of ammonia oxidizers responding to environmental perturbations in dry subhumid ecosystems. Environ Microbiol 17:444-461

Huang Y, Li YY, Yao HY (2014a) Nitrate enhances $\mathrm{N}_{2} \mathrm{O}$ emission more than ammonium in a highly acidic soil. J Soils Sediments 14:146154

Huang T, Gao B, Hu XK, Lu X, Well R, Christie P, Bakken LR, Ju XT (2014b) Ammonia-oxidation as an engine to generate nitrous oxide in an intensively managed calcareous fluvo-aquic soil. Sci Rep 4: $39-50$

IPCC (2013) The physical science basis. Contribution of Working Group I to the fifth assessment report of the Intergovernmental Panel on Climate Change. Cambridge University Press, Cambridge and New York

Jia Z, Conrad R (2009) Bacteria rather than Archaea dominate microbial ammonia oxidation in an agricultural soil. Environ Microbiol 11: $1658-1671$

Kim SW, Miyahara M, Fushinobu S, Wakagi T, Shoun H (2010) Nitrous oxide emission from nitrifying activated sludge dependent on denitrification by ammonia-oxidizing bacteria. Bioresour Technol 101: 3958-3963

Knowles R (1982) Denitrification. Microbiol Mol Biol Rev 46:43-70

Kool DM, Dolfing J, Wrage N, Van Groenigen JW (2011) Nitrifier denitrification as a distinct and significant source of nitrous oxide from soil. Soil Biol Biochem 43:174-178

Krauss M, Krause HM, Spangler S, Kandeler E, Behrens S, Kappler A, Gattinger A (2017) Tillage system affects fertilizer-induced nitrous oxide emissions. Bio Fertil Soils 53:49-59

Liu YR, Delgado-Baquerizo M, Trivedi P, He JZ, Singh BK (2016) Species identity of biocrust-forming lichens drives the response of soil nitrogen cycle to altered precipitation frequency and nitrogen amendment. Soil Biol Biochem 96:128-136

Liu R, Hayden HL, Suter H, Hu HW, Lam SK, He JZ, Chen D (2017) The effect of temperature and moisture on the source of $\mathrm{N}_{2} \mathrm{O}$ and contributions from ammonia oxidizers in an agricultural soil. Bio Fertil Soils 53:141-152

Ma J, Ma ED, Xu H, Yagi K, Cai ZC, Coleman D (2009) Wheat straw management affects ch4 and $\mathrm{N}_{2} \mathrm{O}$ emissions from rice fields. Soil Biol Biochem 41:1022-1028

Minick KJ, Pandey CB, Fox TR, Subedi S (2016) Dissimilatory nitrate reduction to ammonium and $\mathrm{N}_{2} \mathrm{O}$ flux: effect of soil redox potential and $\mathrm{N}$ fertilization in loblolly pine forests. Bio Fertil Soils 52:601614

Morley N, Baggs EM, Dorsch P, Bakken L (2008) Production of NO, $\mathrm{N}_{2} \mathrm{O}$ and $\mathrm{N}_{2}$ by extracted soil bacteria, regulation by $\mathrm{NO}_{2}{ }^{-}$and $\mathrm{O}_{2}$ concentrations. FEMS Microbiol Ecol 65:102-112

Ravishankara AR, Daniel JS, Portmann RW (2009) Nitrous oxide $\left(\mathrm{N}_{2} \mathrm{O}\right)$ : the dominant ozone-depleting substance emitted in the 21 st century. Science 326:123-125

Rosa D, Rowlings DW, Biala J, Scheer C, Basso B, Mcgree J, Grace PR (2016) Effect of organic and mineral $\mathrm{N}$ fertilizers on $\mathrm{N}_{2} \mathrm{O}$ emissions from an intensive vegetable rotation. Bio Fertil Soils 52:1-14

Shaw LJ, Nicol GW, Smith Z, Fear J, Prosser JI, Baggs EM (2006) Nitrosospira spp. can produce nitrous oxide via a nitrifier denitrification pathway. Environ Microbiol 8:214-222

Shcherbak I, Millar N, Robertson GP (2014) Global metaanalysis of the nonlinear response of soil nitrous oxide $\left(\mathrm{N}_{2} \mathrm{O}\right)$ emissions to fertilizer nitrogen. Proc Natl Acad Sci U S A 111:9199-9204
Singurindy O, Richards BK, Molodovskaya M, Steenhuis TS (2006) Nitrous oxide and ammonia emissions from urine-treated soils. Vadose Zone J 5:1236-1245

Smith KA, Thomson PE, Clayton H, McTaggart IP, Conen F (1998) Effects of temperature, water content and nitrogen fertilisation on emissions of nitrous oxide by soils. Atmos Environ 32:3301-3309

Stevens RJ, Laughlin RJ, Burns LC, Arah JRM, Hood RC (1997) Measuring the contributions of nitrification and denitrification to the flux of nitrous oxide from soil. Soil Biol Biochem 29:139-151

Szukics U, Abell GCJ, Hodl V, Mitter B, Sessitsch A, Hackl E, Zechmeister-Boltenstern S (2010) Nitrifiers and denitrifiers respond rapidly to changed moisture and increasing temperature in a pristine forest soil. FEMS Microbiol Ecol 72:395-406

Szukics U, Hackl E, Zechmeister-boltenstern S, Sessitsch A (2012) Rapid and dissimilar response of ammonia oxidising archaea and bacteria to nitrogen and water amendment in two temperate forest soils. Microbiol Res 167:103-109

USDA (1994) Keys to soil taxonomy. United States Department of Agriculture, Soil Conservation Service, 6th edn., p 306

Wan Y, Ju X, Ingwersen J, Schwarz U, Stange CF, Zhang F, Streck T (2009) Gross nitrogen transformations and related nitrous oxide emissions in an intensively used calcareous soil. Soil Sci Soc Am J 73(1):102

Wang N, Ding LJ, Xu HJ, Li HB, Su JQ, Zhu YG (2015) Variability in responses of bacterial communities and nitrogen oxide emission to urea fertilization among various flooded paddy soils. FEMS Microbiol Ecol 91:fiv013. doi:10.1093/femsec/fiv013

Wang Q, Zhang LM, Shen JP, Du S, Han LL, He JZ (2016a) Nitrogen fertiliser-induced changes in $\mathrm{N}_{2} \mathrm{O}$ emissions are attributed more to ammonia-oxidising bacteria rather than archaea as revealed using 1octyne and acetylene inhibitors in two arable soils. Bio Fertil Soils 52:1163-1171

Wang Q, Hu HW, Shen JP, Du S, Zhang LM, He JZ, H LL. (2016b) Effects of the nitrification inhibitor dicyandiamide (DCD) on $\mathrm{N}_{2} \mathrm{O}$ emissions and the abundance of nitrifiers and denitrifiers in two contrasting agricultural soils. J Soils Sediments. doi:10.1007/s11368-016-1633-9

Wrage N, Velthof GL, van Beusichem ML, Oenema O (2001) Role of nitrifier denitrification in the production of nitrous oxide. Soil Biol Biochem 33:1723-1732

Ying JY, Li XX, Wang NN, Lan ZC, JZ H, Bai YF (2017) Contrasting effects of nitrogen forms and soil $\mathrm{pH}$ on ammonia oxidizing microorganisms and their responses to longterm nitrogen fertilization in a typical steppe ecosystem. Soil Biol Biochem 107:10-18

Zhang YY, Mu YJ, Zhou YZ, Tian D, Liu JF, Zhang CL (2016) NO and $\mathrm{N}_{2} \mathrm{O}$ emissions from agricultural fields in the North China Plain: origination and mitigation. Sci Total Environ 551:197-204

Zhu X, Burger M, Doane TA, Horwath WR (2013a) Ammonia oxidation pathways and nitrifier denitrification are significant sources of $\mathrm{N}_{2} \mathrm{O}$ and NO under low oxygen availability. Proc Natl Acad Sci U S A 110:6328-6333

Zhu X, Silva LCR, Doane TA, Wu N, Horwath WR (2013b) Quantifying the effects of green waste compost application, water content and nitrogen fertilization on nitrous oxide emissions in 10 agricultural soils. J Environ Qual 42:912-918

Zhu T, Zhang J, Huang P, Suo L, Wang C, Ding W, Meng L, Zhou K, Hu $\mathrm{Z}$ (2015) $\mathrm{N}_{2} \mathrm{O}$ emissions from banana plantations in tropical China as affected by the application rates of urea and a urease/nitrification inhibitor. Bio Fertil Soils 51(6):673-683 